\title{
Sarcomatoid Transitional Cell Carcinoma
}

National Cancer Institute

\section{Source}

National Cancer Institute. Sarcomatoid Transitional Cell Carcinoma. NCI Thesaurus. Code C4120.

A poorly differentiated transitional cell carcinoma characterized by the presence of malignant cells with spindle cell morphologic features. 